Гордана С. ДРАГИН Универзитет у Новом Саду Филозофски факултет
Оригинални научни рад

Примљен: 06.11.2019.

Прихваћен: 12.02.2020.

\title{
УПОТРЕБНА ВРЕДНОСТ ПРОЗОДИЈСКЕ НОРМЕ КОД СТУДЕНАТА У НОВОМ САДУ**
}

\begin{abstract}
У раду се говори о употребној вредности прозодијске норме код студената новосадског Филозофског факултета. Анализирају се следећи феномени: природа акцента, инвентар и дистрибуција акцентованих прозодема у актуелном говору студентске популације. Што се тиче инвентара прозодема, посебно се скреће пажња на укидање тонских контраста у кратким акцентованим слоговима и на утирање квантитетских опозиција вокала иза акцента. Од дистрибутивних правила обраћа се пажња на стабилизовање силазног акцента ван првог слога у речи и на преношење акцента на проклитику. Од прозодијских алтернација анализирају се оне квантитетског и квантитетско-квалитетског типа, као и алтернација места акцентоване прозодеме. Закључује се да поменуте неутрализације воде до потпуног нивелисања свих разлика међу акцентованим прозодемама и једино истичу као важно место акцента у речи.

Кључне речи: прозодијска норма, употребна вредност, природа акцента, инвентар акцентованих прозодема, дистрибуција акцентованих прозодема, тонска неутрализација.
\end{abstract}

Позната је ствар да се у циљу успешне комуникације међу образованом популацијом дијалекатске разлике нивелишу усвајањем норми којима је прописан стандардни језик. Наиме, различите су ситуације у којима се употребљава стандард од оних у којима се комуницира на народном говору (дијалекту). Употреба стандардног језика везана је, најпре, за школу на свим нивоима - од основне до универзитета (Јокановић Михајлов 2012).

У раду ће бити речи о употребној вредности прозодијске норме, тј. очекиваним акценатским иновацијама ${ }^{1}$ код студентске популације новосадског Филозофског факултета. Корпус представља разговорни језик 40 студената Филозофског факултета у Новом Саду са студијских група Српки језик и

\footnotetext{
*gordanadragin19@gmail.com

** Рад је настао у оквиру пројекта Дијалектолошка истражсивања српског језичког простоpa (148001) који финансира Министарство просвете, науке и технолошког развоја Републике

${ }^{1} \mathrm{O}$ акценатским иновацијама у стандардном српском језику в. Драгин 2016.
} Србије. 
књижевност и Српска књижевност и језик. Важно је нагласити да се, пре свега, узимао у обзир дијалог студент - професор у формалним ситуацијама као што су одговарање на испиту, разговор на часу, консултације у вези са израдом семинарског, дипломског, мастер или докторског рада и слично, тј. ситуације када се очекивало да студент као средство комуникације користи стандардни језик. Међу испитаницима било је студената са 4 дијалекатска подручја: шумадијско-војвођанског, смедеревско-вршачког, косовско-ресавског и из призренско-тимочке дијалекатске зоне. Овакав избор испитаника направљен је да би се у њиховом говору занемарио утицај дијалекатских црта на (не)поштовање акценатске норме, заправо, да би се уочиле опште црте поменуте појаве. Поред тога, користиће се подаци из студије Говор Новог Сада, књига 1: Фонетске особине који се односе и на говор студентске популације ${ }^{2}$.

Обратићемо пажњу на природу акцента, инвентар и дистрибуцију прозодема у актуелном говору студентске популације Новог Сада.

\section{Природа акцента у актуелном говору студентске популације}

На основу инструменталних мерења, запажа се да је природа акцената у говору студентске омладине у Новом Саду знатно другачија од оне која се сматра стандардном. Мисли се, пре свега, на чињеницу да је краткоузлазни акценат краћи од краткосилазног (Марковић/Бјелаковић 2009а: 148-158). Експериментална мерења показала су, такође, да у говору млађе генерације, дакле и студентске популације, краткоузлазни акценат на двосложним речима карактерише силазни тон на акцентованом вокалу и велики узлазни интервал између вокала у иницијалном и финалном слогу, што значи да се акцентовани вокал одликује најчешће силазном интонацијом. За тросложне речи са краткоузлазним акцентом на првом слогу, такође, важи да је тон прво силазни, па потом узлазни у интервалу између вокала у иницијалном и медијалном слогу. Међутим, вокал у медијалном слогу има најчешће узлазно тонско кретање иако се ова особина губи ако се реч нађе у финалној позицији у реченици (Средојевић 2009: 190).

\section{Инвентар прозодема}

Што се тиче инвентара прозодема, после анализе сакупљене грађе, међу иновације спадају следеће промене:

a) укидање тонских контраста у кратким акцентованим слоговима, што значи пренебрегавање разлике између (“) и ( `) акцента.

\footnotetext{
${ }^{2}$ Од укупног броја испитаника који су интервјуисани за потребе студија из монографије која се бави акценатском проблематиком $1 / 4$ су студенти.
} 
Забележени су ови примери:

аполӥтичан, вӧда, Вӧјводина, у Вӧјводини, гӧри, дӓнас, дӧбро, долӥна, жёна, жйвот, извӧлте, јёсен, Констӓнтин, кӧса, лепӧта, мйнистар, пӧбеди (З.л.јд. през.), премӥјер, седмадёсет, слобӧде, сӧкак, толӥко;

да бу̀де, за̀једно, зѐмљу, оेбласти, пѐсник, ро̀дбином, трёбало, у̀гао, у цѐнтру (Драгин 2005: 279).

Преовлађују примери са акцентом на пенултими испред кратке ултиме, али се појава шири и према почетку речи, тј. према иницијалном слогу вишесложних речи. Фрекветнија је неутрализација у корист краткосилазног, док се краткоузлазни јавља у знатно мање примера.

б) утирање квантитетских опозиција вокала иза акцента илуструје се следећим забележеним примерима (Бјелаковић/Марковић 2009):

1) у Гјд. им. ж.р. на - $а$ (од нӧве стра̀ницее, од триि тӓчке, за при́мер једнйне, без сѐстре, неิма једйнице);

2) у Ијд. им. ж.р. на -а (мла́дом држсавом, књйгом, са пёсмом, јӓсном стра̀тегијом, са баิјком, за праิвдом, са маิлом свёском);

3) у финалном вокалу код Гмн именица, заменица, придева и бројева (вйше дѐвојака од му̀шкараца, од нёпознатих же́на, неิмам ко̀верата, од нӓших миेнистара, пӱно ра́зличитих наิ-

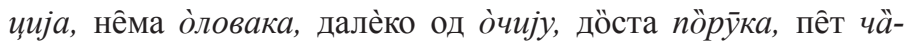
со̄ва);

4) у у финалном вокалу облика заменичко-придевске деклинације

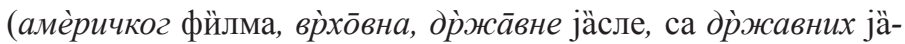
сала, јӓсном речѐницом, пољопрӥвредни, рӓдикалне стрӓнке, рӧђачкој вёзи, ср̈пске страิне, стра̀тешки по̀ступак, суิнчано, неิма у̀вређених; мо̀joj, од нёких, од о̀не гра̂ђе, сво̀joj, тво̀joj);

5) само факултативно у инфинитиву на вокалу основе (ако се дужина и чува, то је увек иза краткоузлазног акцента) (до̀неmи / до̀нети па̀пир и пи́сати пи́смо, у̀зетти / у̀зети две̂ кре́де и по̀че̄ти / по̀чети швв́ьљьати);

6) на тематском вокалу у презенту (дођем, дуิне, за̀пишем, ја̂вим, вйдиш, пӧчнеш, до̀каже, нѐстане, да по̀каже, рѐагује, глёдамо, нӧсимо, вӥде, нӧсе);

7) на вокалу у наставку аориста (ако испитаници „препознају” да се ради о аористу, а не о презенту) (ӥзнесе га, пӧдиже ме, однёсоше, по̀стадоше);

8) само факултативно на пенултими код глаголског прилога садашњег (вла́дајући, пúmyћu / núj̄̄ћu, жи́већи / жи́ве̄ћu);

9) на вокалу испред наставка -вши код глаголског прилога прошлог, али само факултативно у позицији иза краткоузлазног акцента (до̀невши/до̀неввши, о̀дневши, рѐкавши / рѐка̄вши);

10) код глаголског придева трпног (дӧдана зӓпета, сӓстанак је ӧдржан, о̀кренут нӓопако, ӱзета те̂ма, у̀својен плаิн, ѝстурена реิч, са оेствареним бо́довима); 
11) код великог броја именичких суфикса (стӱдентски лѐкар, дӧгађај, прёкршај, намѐштање, изда́ғье, са̀радник, одгово́рност, у̀мешаност, пѝтање, исто̀ричар, премѝјер) - али дуг вокал у овим облицима често се факултативно чува иза краткоузланог акцента (но̀са̄ч / но̀сач, во̀дичч / во̀дич, доेбитнйк/до̆битник, мйшӣћ / мѝшић, мла̀дйћ / мла̀дић, станѝо̄л/ станѝол, хѐро̄j /хѐрој, телѐфо̄н/ телѐфон).

Тонска неутрализација је, и иначе, „много изразитија у говору младе популације (...)", а скраћивање дугих прозодема „ван акцента (...) је спроведено радикално” и не само у говору млађе популације (Петровић 1996: 97).

Структурално гледајући, грађа показује да се без остатка скраћује дуги вокал иза силазних акцената и иза неакцентоване дужине и краткоће у отвореном, затвореном и медијалном слогу (вӥде, нӧсе, од триि тӓчке; немма, дуิне; вр̀ховвна, др̀жа̄вне јӓсле; за при́мер једнѝне, неิма о̀ловака; књйгом, са маิлом свёском; са баิјком, за праิвдом; рӧђачкој вёзи, сӓстанак је ӧдржан, о̀кренут нӓопако, са̀радник).

Иза узлазних акцената дужина се само факултативно скраћује (за при́мер једнѝне, без сѐстре, од нёпознатих же́на, мла̀дић, одгово́рност, сво̀јој,

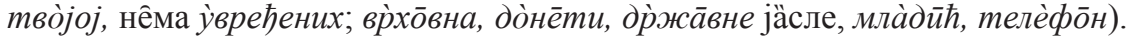

У облицима Гмн. најчешће скраћују се обе дужине (вйше дѐвојака од му̀шкараца), док она дуже опстаје иза кратких акцената, у медијалној позицији у речи, тј. ако је у непосредној близини акцентованог слога (дӧста пӧрӯка).

У студији Фонетика у зборнику радова са заједничком оквирном темом Српски језик на крају века, Драгољуб Петровић говорећи о инвентару и дистрибуцији прозодема у српском стандардном језику истиче да се радикално спроводи скраћивање дужина иза акцента и додаје „Процес је толико узнапредовао да се с правом може рећи да послеакиенатског квантитета данас нема" (Петровић 1996: 93). Скраћивање овога типа (у стандардном прозодијском систему, бар у његовом разговорном изразу који нам је у фокусу) може се прихватити и као тенденција, као пут ка тонској неутрализацији што у говору студентске популације почиње да се реализује, бар кад су у питању кратки акценти.

На основу презентованих примера јасно је да се дужине које су се раније доследно чувале сада опстају само факултативно, а факултативно сачуване дужине доследно се скраћују.

\section{Дистрибуција прозодема}

Најмаркантнија иновација која се тиче дистрибуције акцента у говорној пракси новосадске студентске популације и уопште у вернакулару града (не само Новог Сада) јесте појава силазних акцената у непрвом слогу у речи. Ова појава представљана је често и веома детаљно у радовима наших фо- 
нолога (Јоцић и др. 1982; Петровић 1992, 1996; Фекете 2000; Драгин 2005 , 2009, 2012; Јокановић/Михајлов 2007, 2012; Средојевић 2009; Бошњаковић/Регодић 2007, итд.). Стабилизовање силазног акцента ван првог слога у речи забележено је у следећим примерима:

а) асистёнт, девӧјчӣца гмн, емйсиија гмн, лепӧтӣца Гмн, манипулӓнт, фолирӓнт; веровӓтно, пољопрӥвредни, понёшто; у интервјӱу, конкурёнтна; изузётно, комплётно, поред стандарног лика асѝстент, докуेмент, првоेбитно;

б) интервју, макрамеิ; у Аустраิлији, југозаิпадни, територији; администраิторима, инвестиิщчиа, поједиิнацуа гмн, задаิтака Гмн, омладйнаца гмн, послодаิваца гмн, али чује се знатно ређе и стандардно амба̀са̄дора, телѐвйзију, међу̀тим, међу̀тӣм, органѝза̄тори, Југо̀сла̄вија - в. Драгин 2005: 281; Фекете 2000: 1314.

Ради се, углавном, о речима које потичу из страних језика, затим ту су домаће сложенице, са спојним вокалом или без њега и облици Гмн (Фекете 2000: 1313, 1314). У вези са овим феноменом, Петровић примећује да долази до нарушавања класичних дистибутивних правила ,а томе доприносе и све радикалнија непреношења акцента у проклитичким спојевима" (Петровић 1996: 97).

По усменом сведочењу већине испитаника, студената (без обзира на дијалекатску припадност), појава силазних акцената на непрвом слогу у речи, сматра се регуларном, док се његова стандардна позиција, најчешће сматра необичном, чак неприхватљивом појавом. Овакав став о овој појави сигуран је знак да је дистрибутивно правило о положају силазног акцента само на првом слогу у речи озбиљно уздрмано.

\section{Преношење акцента на проклитику}

Прозодијска појава преношења силазних акцената са првог слога у речи на проклитику нормативно је правило (Белић 1951: 232), али говорна пракса све више оповргава ову чињеницу. Исцрпна литература о овој теми представљена је у Петровић 1996: 89-98. Већ је констатовано у литертури ${ }^{3}$ да је на локалним новосадским медијима „померање акцента на проклитику само факултативна појава” (Драгин 2005: 281), као и то да „средњошколци и студенти спорадично померају акценат на проклитику” (Бошњаковић 2009: 80). Да се ради о улози традиције у преношењу акцента на проклитике, тврде Ивић и др. (1994: 88-89) и истичу да се акценат неће преносити у синтагмама које су непознате говорном лицу, што значи да се појава преношења акцента на проклитику доживљава као шум у комуникацији. Млађе генерације, међу њима и студентска, ову појаву доживљавају као архаичну и регионалну, тј.

${ }^{3}$ в. Петровић 1999: 230, Драгин 2005: 281, Јокановић Михајлов 2007. 
као јасну маркацију о дијалекатском пореклу, и с тога је избегавају (Суботић 2005: 143).

Нећемо наводити све забележене примере са (не)пренесеним акцентом на проклитику, него ће се сумарно приказати резултати до којих се дошло уз запажања о свакодневном говору младих Новог Сада.

Са највећим индексом фреквенције јесу примери са старим преношењем акцента на проклитику, дакле када је пренесени акценат краткосилазни (

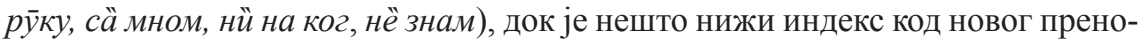

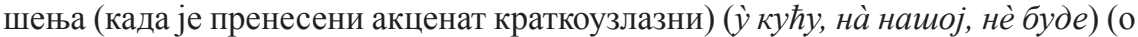
процентуалним подацима в. Бошњаковић 2009: 79-100). Преношење је, како је напред речено, редовно у сталним синтагмама (сӓ мном, нй на ког), као и код негираних глагола са силазним акцентом на иницијалном слогу у позитивној форми (нё знам, нѐ види). Присутна је свест код студената да би дошло до малопре помињаног шума у комуникацији када се акценат не би пренео на проклитику не и остао на пунозначном глаголу (не знаิм, не вйди) (Јокановић Михајлов 2012: 30). Маркантан је и податак да је преношења акцента на проклитику знатно ређе, готово га и нема, код студената са територије говорног поручја које не припада дијалектима који су ушли у стандард (херцеговачко-крајишки и шумадијско-војвођански) јер ретко се акценат преноси на проклитику у староштокавским говорима који чувају старо место акцента. У закључак се може додати и чињеница да је преношење акцента на проклитику у актуелном говору новосадске студентске популације знатно ређе него што је то, рецимо, код старијих Новосађана (Бошњаковић 2009: 81).

Скраћивање неакцентованог квантитета о којем је било речи само је део свеобухватне тенденције ка скраћивању квантитета уопште, дакле и под акцентом. Примећене су квантитетске, као и квантитетско-квалитетске, алтернације акцентованих прозодема. Забележени су ови примери:

'> : библиотѐка, у гра̀dy, нёколико да̀на, записѝвала, испѝтати, у Нѝmy, преглѐдала два̂ да̀на, pàcnycm, учио̀нициа, на факултѐту;

' > ": грӓна лингвѝстике, нѐдељу дӓна, вйше месёцฺи, нёма вйше колёга, трй пӱта полӓгала, йма рӓзлога, са факултёта;

ᄀ > ": нӧва вёст, дӓн - двӓ, трй дӓна, трй пӱта днёвно, кӓжем, нёма, прӓзник, на сйнце, Црина Гӧра;

> ` : ма̀ла грёшка, нѐмате, пѝшемо зӓједно, ра̀дите;

О алтернацијама овога типа в. Драгин 2005: 280 и Петровић 1996: 95, 96.

Честа је појава акценатских дублета. Слободан је избор у томе да ли ће се једна или друга стандардна варијанта неког облика усталити у некој говорној заједници. Када се изабрана варијанта наметне као једина могућа и на другим теренима српскога језика (где је дотада била непозната), можемо је с правом сматрати иновацијом.

Алтернација места акцента маркирана је код префигираних глагола I и VII Белићеве врсте у презенту, императиву и инфинитиву: по̀несем, о̀несеш, до̀несе, где по̀стоје, до̀неси, за̀неси, ра̀скрстите, по̀nустити, ѝсnећи, за̀тећи, про̀нашла, ѝзашла, о̀кречио, нӧге на̀текле, за̀текли, о̀дрекла. 
Унифицира се место акцента тако што се помера за један слог ка почетку речи и углавном доспева на први слог, аналошки час према инфинитву час према презенту. Код глаголског придева трпног неких глагола акценат је на 2. слогу: затѐчена, одсѐчена, залѝвена, покриेвено.

У примерима прекр̀шили, помѝслила, осмѝслила, за́кон акценат, заправо, остаје на старом месту само мења интонацију, од силазног постаје узлазни.

Алтернација места и квантитета акцента детектована је у прилозима за место (ода́вде : о̀давде : о̀да̄вде, ода́тле : о̀датле : о̀а̄тле, ода́кле : о̀дакле : о̀да̄кле, ону̀да, оेнуда, ову̀да, о̀вуда), затим у футуру где се избор прави у правцу иницијалног места акцента (про̀на̄ћu : прона́ћu, ѝза̄ћu : иза́ћu, nòвйћu: пову́ћu).

Код прилога за место уочљива је предност акценатских ликова са краткоузлазним на првом слогу без дужине на слогу који следи (о̀двде, о̀датле, оेдакле, оेнуда, оेвуда).

У примерима комунйцийрати, по̀zӯpajy, са̀кӯnљаjу преузима се акценат херцеговачких и црногорских говора херцеговачко-крајишког дијалекта.

Број дублетних форми у прозодијском систему српског језика веома је висок (Ивић 1965: 135-144) и регуларна је тежња да се он упрости тако што би се озваничиле регионалне варијанте. Другим речима, развој у погледу дублета иде у правцу симплификације. И овде је запажена тежња сложеног српског прозодијског система да се упрости, тј. достигне што већи степен економичности. О акценатским дублетима в. више у Јокановић Михајлов 2012: 58-65.

Поменуте неутрализације, тонске и квантитетске, воде до потпуног нивелисања свих разлика међу акцентованим прозодемама и истичу једино као важно место акцента у речи. То је једна од прозодијских одлика балканског језичког савеза и најмаркантнија одлика, по речима П. Ивића, иновативне, балканизиране призренско-тимочке говорне зоне (Ивић 1990: 193). У говору студената зебележено је и доста примера са експираторним акцентом од којих доносим само део ${ }^{4}$ одбрАнила мАстер, полОжила, прИјавим Испит, нИсам дОлазила, понОвила дрУгу, пОништила. О овоме в. детаљније код Петровић 1996: 97.

Само две студенткиње у групи од 40 испитаника потичу са терена призренско-тимочке говорне зоне, тј. из Ниша, што доказује да ова појава није, како би се очекивало, дијалекатске природе.

На једном месту Петровић примећује да „Прозодијске промене које смо

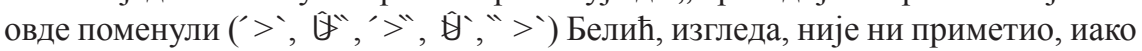
се за њих може рећи да спадају у „тековине” српског прозодијског система развоја последњих деценија" (Петровић 2010: 373). Могуће је и да у време кад је Белић писао о променама у нашем прозодијском систему (средина 20. века) поменуте иновације нису биле толико маркантне и широко заступљене у говору, готово, свих представника српског језика без обзира на географско, тј. дијалекатско порекло и узраст као што су то данас. Као што је већ при-

${ }^{4}$ Због техничких немогућности, великим словом биће маркиран вокал у акцентованом слогу. 
мећено у ранијим радовима на исту тему (Драгин 2005: 280; Петровић 2010: 380 ; и др.) и овде је запажено да су поменуте иновације најдаље одмакле у говору младих.

Јасно је да се прозодијски систем стандардног језика у разговорном језику млађе, па и студенетске, популације радикално разграђује. Употребна вредност прозодијске норме у многим детаљима оповргава успостављену норму. Иновације о којима је реч, дијалекатски засноване или бар скоро увек потврђене у неком народном говору, често имају и карактер престижних особина говора града.

После анализиране грађе све више се отвара простор дилеми која гласи: да ли је сазрело време да се прозодијска норма стандардног језика ревалоризује, мења бар у неком детаљу ${ }^{5}$ како би се избегао све већи раскорак између прописане норме и њене примене.

\section{ЛИТЕРАТУРА}

Белић 1951: Александар Белић, Из новије акцентуације, Наш језик, н. с. књ. II, св. 7-10, 227-237.

Бјелаковић/Марковић 2009: Исидора Бјелаковић, Маја Марковић, Послеакценатске дужине у говору Новог Сада, Говор Новог Сада, свеска 1: фонетске особине, Лингвистичке свеске бр. 8, Нови Сад, 110-128.

Бошњаковић/Регодић 2007: Жарко Бошњаковић, Небојша Регодић, О неким прозодијском карактеристикама језика новосадских медија (ТВ Панонија), Прилози проучавању језика, 38, Нови Сад, 263-315.

Бошњаковић 2009: Жарко Бошњаковић, Преношење акцента на проклитику у говору Новог Сада, Говор Новог Сада, свеска 1: фонетске особине, Лингвистичке свеске бр. 8, Нови Сад, 79-109.

Драгин 2005: Гордана Драгин, Прозодијске особине говора спикера (новинара) РТВ Нови Сад, Зборник Матище српске за филологију и лингвистику, 48/1-2, 277-282.

Драгин 2009: Гордана Драгин, Дистрибуција послеакценатских дужина у језику медија, Говор Новог Сада, свеска 1: фонетске особине, Лингвистичке свеске бр. 8, Нови Сад, 129-140.

Драгин 2016: Гордана Драгин, Иновације на прозодијском плану у српском језику, Дијалекти српскога језика: истраживања, настава, књижевност 1 (ур. Радмила В. Жугић), Педагошки факултет у Врању, Универзитет у Нишу, Лесковац - Врање, 303-313.

Ивић/Лехисте 1996: Павле Ивић, Илзе Лехисте, Прозодија речи и реченице у српскохрватском језику, Павле Ивић, Целокупна дела, VII/2, Сремски Карловци, Нови Сад: Издавачка књижарница Зорана Стојановића.

${ }^{5}$ О проблемима иновирања ортоепске норме в. Јокановић Михајлов 2012: 248-253. 
Ивић и др. 1994: Павле Ивић, Жарко Бошњаковић, Гордана Драгин, Банатски говори шумадијско-војвођанског дијалекта (увод и фонетизам), Cpnски дијалектолошки зборник, 40, Београд.

Јокановић Михајлов 2007: Јелица Јокановић-Михајлов, Акиенат и интонација говора на радију и телевизији, Београд: Чигоја штампа.

Јокановић Михајлов 2012: Јелица Јокановић-Михајлов, Прозодија и говорна култура, Београд: Друштво за српски језик и књижевност Србије.

Јоцић и др. 1982: Мирјана Јоцић, Драгољуб Петровић, Љиљана Суботић, Комуникацијске и говорно-језичке карактеристике ТВ Дневника Телевизије Нови Сад на српскохрватском језику, (ур. Ђ. Поповић) Одељење за истраживање програма и аудоторијума радио-телевизије, Нови Сад.

Марковић/Бјелаковић 2009а: Маја Марковић, Исидора Бјелаковић, Квантитет наглашених вокала у говору Новог Сада, Говор Новог Сада, свеска 1: фонетске особине, Лингвистичке свесеке бр. 8, Нови Сад, 148-158.

Марковић/Бјелаковић 2009б: Маја Марковић, Исидора Бјелаковић, Квантитет дугих посттоничних вокала у говору Новог Сада, Говор Новог Сада, свеска 1: фонетске особине, Лингвистичке свесеке бр. 8, Нови Сад, 141-147.

Петровић 1996: Драгољуб Петровић, Фонетика, у: Српски језик на крају века, Београд: Институт за српски језик САНУ, Службени гласник, 87-110.

Петровић 1999: Драгољуб Петровић, Две прозодијске норме?, Актуелни проблеми граматике српског језика - Зборник радова са другог међународног научног скупа, Суботица - Београд, 227-231.

Петровић/Гудурић 2010: Драгољуб Петровић, Снежана Гудурић, Фонологија српског језика, Институт за српски језик САНУ, Београд - Нови Сад: Београдска књига, Матица српска.

Средојевић 2009: Дејан Средојевић, Експериментално-фонетско испитивање краткоузлазног акцента у новосадском говору - тонска компонента, Говор Новог Сада, свеска 1: фонетске особине, Лингвистичке свеске бр. 8, Нови Сад, 159-191.

Суботић 2005: Љиљана Суботић, Ортоепска и ортографска норма стандардног српског језика, Одсек за медијске студије, Нови Сад: Филозофски факултет.

Фекете 2000: Егон Фекете, Неке појаве систем(ат)ског нарушавања акценатске норме, Јужнословенски филолог, LVI/3-4, 1297-1329. 
Gordana S. Dragin

USE VALUE OF PROSODIC NORM IN THE SPEECH OF STUDENTS IN NOVI SAD

\section{Summary}

The paper deals with the use value of the prosodic norm in the speech of students of the Faculty of Philosophy in Novi Sad. The following phenomena are analyzed: the nature of the accent, the inventory and distribution of accented prosodeme in the current speech of the student population, the elimination of tonal contrasts in short accented syllables, the suppression of quantitative oppositions of the vocals behind the accent, the stabilization of the descending accent beyond the first syllable in words, the transfer of accent to a proclitic , the alternations of place, quantity and quality of the accent, the leveling of all the differences between the accented prosodemes.

Key words: prosodic norm, use value, nature of accents, inventory of accented prosodemes, distribution of accented prosodemes, tone neutralization. 